\title{
Renier-Gabreels-Jasper syndrome
}

\author{
INSERM
}

\section{Source}

INSERM. (1999). Orphanet: an online rare disease and orphan drug data base. RenierGabreels-Jasper syndrome. ORPHA:93975

Renier-Gabreels-Jasper syndrome is an X-linked mental retardation (XLMR) syndrome belonging to the group of conditions characterised by the association of intellectual deficit with hypotonic facies (Mental retardation, X-linked-hypotonic facies; see this term). 